\title{
FORMULATION EVALUATION AND OPTIMIZATION OF IMMEDIATE RELEASE TABLET OF ACECLOFENAC BY DIRECT COMPRESSION METHOD
}

\author{
JAHAN NUR RAHMAN HAZARIKA*1, PULAK DEB ${ }^{1}$ \\ ${ }^{1}$ Girijananda Chowdhury Institute of Pharmaceutical Science, Azara, Guwahati \\ Email: jahanh1994@gmail.com
}

Received: 05 Jan 2017, Revised and Accepted: 31 Apr 2017

\begin{abstract}
Objective: The objective of present work is to formulate and evaluate immediate release tablets of aceclofenac. Aceclofenac is effectively acting as non-steroidal anti-inflammatory drug (NSAID) of the phenylacetic acid group, which has properties such as anti-inflammatory, analgesic and antipyretic when given orally.

Methods: First Pre-formulation studies were carried out such as FTIR, solubility, bulk and tapped density, hounars ratio, Carr's index, the angle of repose etc. Then the tablets were prepared by direct compression using super disintegrating agents (sodium starch glycolate). To obtain the desired optimum formulation several formulations had been performed with different excipients and their ration. For each formulation, post formulation parameters are determined including hardness, weight variation, friability, disintegration and in vitro dissolution, wetting time, water absorption ratio etc.
\end{abstract}

Results: From the test performed it is found that the formulation F8 is best and satisfies all the criteria as immediate release tablet.

Conclusion: From the result, it can be concluded that using Sodium Starch Glycolate at 4\% will give the best in vitro drug release.

Keywords: Immediate release tablet, Aceclofenac, Super disintegrating agents, Direct compression, In vitro dissolution and disintegration time

(C) 2017 The Authors. Published by Innovare Academic Sciences Pvt Ltd. This is an open access article under the CC BY license (http://creativecommons.org/licenses/by/4.0/) DOI: http://dx.doi.org/10.22159/ijcpr.2017v9i3.19972

\section{INTRODUCTION}

Oral routes of drug administration have acceptance of about $50-60 \%$ of total dosage forms. Solid dosage forms have some advantages, which makes it most popular such as administration, accurate dosage, self-medication, pain avoidance [1]. The most popular solid dosage forms are tablets and capsules [2].

An immediate release tablet is that when taken it goes to the stomach and disintegrate instantaneously releasing the drug, which dissolves or disperses in the gastric fluid [3]. Immediate release tablets have the advantages to release the drug immediately within a short period of time [4]. These are those for which $\geq 85 \%$ of labeled amount dissolves within $30 \mathrm{~min}$ [5].

Aceclofenac which is chemically (2-[(2, 6-di chlorophenyl) amine] phenylacetoxy acetic acid) is effective when given orally acts as nonsteroidal anti-inflammatory drug (NSAID) of the phenylacetic acid group, which have properties such as anti-inflammatory, analgesic and antipyretic [6]. The drug works by inhibiting the action of cyclooxygenase (COX) that is involved in the production of prostaglandins (PG) which is accountable for pain, swelling, inflammation and fever [7]. The analgesic efficacy of aceclofenac is given in $100 \mathrm{mg}$ dose. Aceclofenac is practically insoluble in water [8]. It should not be given to people with porphyria or breastfeeding mothers and is not recommended for children. It should be avoided in a pregnant woman because of the risk of having a potent ductusarteriosus in the neonate [9].

The aim and Objective of present work is to formulate and evaluate immediate release tablets by direct compression method using the drug Aceclofenac as a model drug. It was aimed to increase the drug release profile in short duration of time. Evaluation of formulated tablets was done using various quality parameters like hardness, friability, wetting time, disintegration time, in vitro dissolution study [10].

\section{MATERIALS AND METHODS}

\section{Materials}

Aceclofenac, Dibasic Calcium Phosphate, PVP, SLS, Talc were obtained from Balaji Drugs, Mumbai-8, India. Anhydrous Lactose, MCC, starch,
Sodium starch glycolate and Colloidal Silicon Dioxide are obtained from Merk specialist pvt limited, Mumbai-18. All other chemicals used were of analytical grade.

\section{Methods}

Pre-compression parameters

Organoleptic properties [1]

A small amount of sample is examined by simple visualization and colour, texture etc. were determined.

\section{Solubility studies [1]}

A small quantity of the drug sample was taken in a test tube and the solubility was determined by dissolving the drug in $1 \mathrm{ml}$ of various solvents.

\section{Bulk Density $(\rho B)[1]$}

Bulk density is determined by a constant mass method using measuring cylinder. The bulk density of a powder is the ratio of the mass of an untapped powder sample to its volume, including the contribution of the inter-particulate void volume. It is expressed in $\mathrm{gm} / \mathrm{ml}$ and is given by-

Bulk density $(\rho B)=M / V_{o}$

Where,

$\mathrm{M}=$ mass of the powder (weight taken in $\mathrm{g}$ )

$\mathrm{V}_{\mathrm{o}}=$ Void volume (Untapped Volume in $\mathrm{ml}$ )

Tapped density $(\rho \mathrm{T})[1]$

Taped volume is measured by taping measuring cylinder till there is no change of reading. It is expressed in $\mathrm{gm} / \mathrm{ml}$ and is given by-

Tapped density $(\rho \mathrm{T})=\mathrm{M} / \mathrm{V}_{\mathrm{f}}$

Where $\mathrm{M}=$ mass of the powder (weight taken in $\mathrm{g}$ )

$\mathrm{V}_{\mathrm{f}}=$ Tapped Volume (Final bulk volume after tapped in $\mathrm{ml}$ ) 


\section{Hausner ratio [1]}

Hausner ratio is an indirect index to predict of powder flow. It is calculated by the following formula.

Hausner ratio $=$ Tapped density $(\rho \mathrm{T}) /$ Bulk density $(\rho \mathrm{B})$

Hausner ratio is also calculated by following formula

Hausner ratio $=\mathrm{Vo} / \mathrm{Vf}$

\section{Compressibility index (Carr's index) [1]}

Compressibility index (Carr's index) is an indirect parameter to assume flow property of powder. Compressibility index determined by measuring the initial volume (Vo) and final volume (Vf) after complete tapings of powder sample in a measuring cylinder.

$$
\text { Compressibility index }(\mathrm{CI})=\left(\mathrm{V}_{0}-\mathrm{V}_{\mathrm{f}}\right) / \mathrm{V}_{\mathrm{o}} \mathrm{X} 100
$$

Alternatively, compressibility index may be calculated using measured values for bulk density $(\rho \mathrm{B})$ and tapped density $(\rho \mathrm{T})$ as follows.

$$
\text { Compressibility index }=100 \times\{(\rho \mathrm{T}-\rho \mathrm{B}) / \rho \mathrm{T}\}
$$

\section{Angle of repose [1]}

The angle of repose is the three-dimensional angle (relative to the horizontal base) assumed by a cone-like pile of material formed by different methods. The method is fixed height method. In the fixed funnel, the method employs a funnel that was secured with its tip at a given height $(2 \mathrm{~cm})$, above the graph paper that was placed on a flat horizontal surface. Granules or tablet blend were carefully poured through the funnel until the apex of the conical pile just touches the tip of the funnel. Thus, with $r$ being the radius of the base of the conical pile. The angle of repose is calculating using formula.

$\operatorname{Tan} \theta=\mathrm{h} / \mathrm{r}$

Angle of repose $(\theta)=\tan ^{-1}(\mathrm{~h} / \mathrm{r})$

Where, $\mathrm{h}=$ height of the powder pile

$\mathrm{r}=$ radius of pile circle

\section{Absorption spectra of aceclofenac [5]}

The absorption spectra were prepared using phosphate buffer 7.4, in the range of $200-400 \mathrm{~nm}$.

\section{Calibration curve of aceclofenac [5]}

It was prepared by using UV spectrophotometer (Shimadzu, Model no: UV 1800240V). For this $100 \mathrm{mg}$ of the drug was dissolved in phosphate buffer 7.5 and shaken for complete dissolve. Then it was filtered and dilution was done in such a way that the resultant sample was of $2,4,6,8,10$ etc and was analysed under UV spectrophotometer () at the $\lambda \max 273 \mathrm{~nm}$.

\section{FTIR study [6]}

The infrared spectrum was taken for the pure aceclofenac, PVP and Sodium Starch Glycolate. FT-IR studies were carried by $\mathrm{KBr}$ disk method using computer mediated Fourier transformed infrared spectroscopy (FTIR) ().

\section{Preparation of aceclofenac immediate release tablets}

Accurately weighed amounts of Aceclofenac and diluents were blended. To this varying amount of sifted Sodium starch glycolate (SSG) and other excipients were added and together blended and pass through sieve no 80 and thus the mixture is ready for compression which was then compressed by a $8 \mathrm{~mm}$ punch in tablet punching machine.

\section{Post formulation studies}

\section{Appearance [3]}

Prepared tablets were observed and determined for any physical appearance including elegance, shape, colour, surface textures.

\section{Dimensional analyses [3]}

Dimensional analysis includes Thickness and diameter of tablets were determined using Vernier Calliper. Randomly three tablets select from each batch and average values are calculated.

\section{Hardness [3]}

Hardness is measuring the force required to break the tablet using Monsanto hardness tester. The hardness of 3 tablets from a batch are determined. Hardness measured in $\mathrm{kg} / \mathrm{cm}^{2}$.

\section{Weight variation test [3]}

Weight variation test is carried out by taking Individual weights of 20 tablets randomly from the whole batch. Individual weights then compared with the average weight for the weight variations.

$$
\mathrm{PD}=\left[\left(\mathrm{W}_{\text {avg }}-\mathrm{W}_{\text {initial }}\right) /\left(\mathrm{W}_{\text {avg }}\right)\right] \times 100
$$

Where,

$\mathrm{PD}=$ Percentage deviation,

$\mathrm{W}_{\text {avg }}=$ Average weight of tablet,

$\mathrm{W}_{\text {initial }}=$ Individual weight of tablet.

\section{Friability test [3]}

10 tablets were accurately weighted and place in the drum. Rotate the drum 100 times that means $25 \pm 1 \mathrm{rpm}$ for $4 \mathrm{~min}$, and remove the tablets. Remove any loose dust from the tablets and accurately weighed. A maximum mean mass loss from the three samples of not more than $1.0 \%$ is considered acceptable for most products.

$\%$ friability $=($ Initial weight-final weight $) /$ Initial weight $\mathrm{x} 100$

\section{Disintegration test [3]}

Disintegration test is carried out with the help of disintegration apparatus (Rolex India). 1 dosage unit in every tube (six) of the basket were placed. $1 \mathrm{~N} \mathrm{HCl}$ as immersion fluid was used and the temperature is maintained at $37^{\circ} \pm 2{ }^{\circ} \mathrm{C}$. The apparatus was operated till each of the unit dosages come out from the basket.

\section{Drug content [3]}

5 tablets were powdered and $100 \mathrm{mg}$ drug equivalent powder dissolved in buffer $\mathrm{pH}$ 7.5. The volume of the solution made up to 100 $\mathrm{ml}$ by that media. The solution was filtered and diluted 100times and analysed spectrophotometrically (Shimadju, Model no: UV $1800240 \mathrm{~V}$ ) and further calculation carried out to determine drug content in one tablet.

\section{In vitro drug release study [3]}

Those tests were carried out using dissolution test apparatus containing specified volume of $900 \mathrm{ml}$ phosphate buffer 7.5 and the temperature were maintained at $37 \pm 0.50 \mathrm{C}$. The tablets are directly placed in a medium and immediately the paddles were started at the specified rate (50 RPM). Within the time interval specified (15, 30, 45 and $60 \mathrm{~min}) 10 \mathrm{ml}$ of sample are withdrawn. The samples were filtered and from the filtrate $1 \mathrm{ml}$ was dilute to $10 \mathrm{ml}$. These samples are analyzed and further calculation is carried out to get drug release. The drug released data were plotted and tested with zero order (Cumulative \% drug released Vs time).

\section{Wetting time [10]}

A piece of filter paper folded twice was placed in a Petri dish containing $6 \mathrm{ml}$ of phosphate buffer pH7.5. A tablet is put on the paper and the time for complete wetting was measured. Three trials were performed for each batch.

\section{Water absorption ratio [10]}

A piece of filter paper folded twice was placed in a small Petri dish containing $6 \mathrm{ml}$ of water. A tablet is put on the paper and allowed to wet completely. The wet tablet was then weighted. And the water absorption ratio is then determined as follows-

Water absorption ration $(\mathrm{R})=100\left(\mathrm{~W}_{\mathrm{a}}-\mathrm{W}_{\mathrm{b}}\right) / \mathrm{W}_{\mathrm{b}}$

Where,

$\mathrm{W}_{\mathrm{b}}=$ weight of the tablet before absorption

$\mathrm{W}_{\mathrm{a}}=$ weight of the tablet after absorption 
Table 1: Preformulation results

\begin{tabular}{lll}
\hline S. No. & Parameters & Results \\
\hline 1 & Organoleptic Properties & \\
& Bulk Characteristics & Crystalline powder \\
& Colour & Off white \\
& Odour & Odourless \\
2 & Solubility & $>$ Practically insoluble in water \\
& & $>$ Freely soluble in acetone \\
3 & & $>$ Soluble in alcohol \\
4 & Bulk density & 0.5339 gm $/ \mathrm{ml}$ \\
5 & Tapper density & $0.9268 \mathrm{gm} / \mathrm{ml}$ \\
6 & Hausner ratio & 1.80 \\
7 & Compressibility index & 42.31 \\
8 & Angle of repose & 38.65 \\
\hline
\end{tabular}

Table 2: Absorbance of aceclofenac at different concentration

\begin{tabular}{lll}
\hline S. No. & Concentration $(\boldsymbol{\mu g} / \mathbf{m l})$ & Absorbance \\
\hline 1 & 0 & 0 \\
2 & 2 & 0.1412 \\
3 & 4 & 0.2342 \\
4 & 6 & 0.3038 \\
5 & 8 & 0.4351 \\
6 & 10 & 0.544 \\
7 & 12 & 0.6122 \\
8 & 14 & 0.7199 \\
9 & 16 & 0.7993 \\
10 & 18 & 0.941 \\
11 & 20 & 0.9789 \\
\hline
\end{tabular}

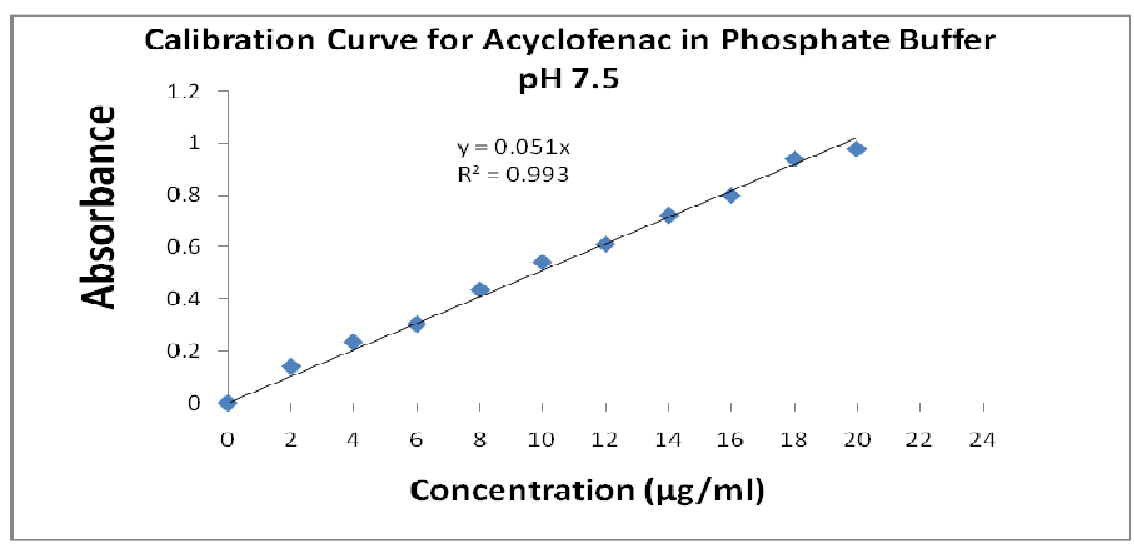

Fig. 1: FTIR

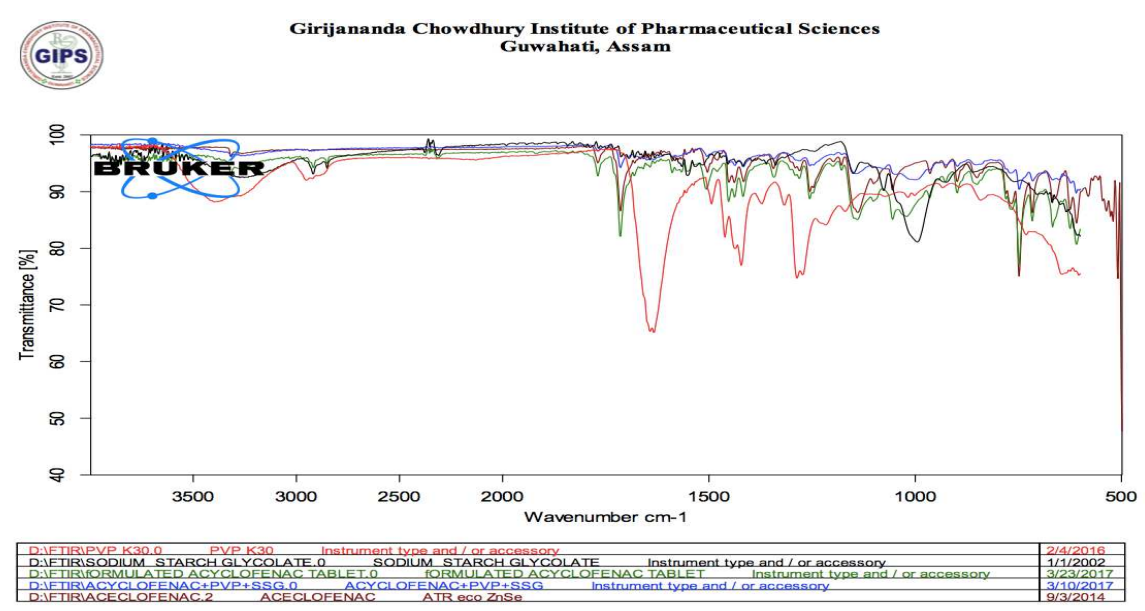

Fig. 2 
Table 3: Description of structure obtained form FTIR of DRUG

\begin{tabular}{lll}
\hline S. No. & Bands & Absorption \\
\hline 1 & N-H(S) & 3729.87 \\
2 & O-H(S) & 3317.10 \\
3 & C-H(S) & 3050 \\
4 & C=O(S) & 1714.71 \\
5 & Aromatic Ring & 1588.69 \\
6 & C-O-C(S) & 1255.27 \\
7 & C-Cl(S) & 748.29 \\
\hline
\end{tabular}

Table 4: Formulation of aceclofenac tablets

\begin{tabular}{|c|c|c|c|c|c|c|c|c|c|}
\hline S. No. & Ingre diants & F1 & F2 & F3 & F4 & F5 & F6 & F7 & F8 \\
\hline 1 & Anhydrous lactose & $\begin{array}{l}31.25 \\
(18 \%)\end{array}$ & $\begin{array}{l}22.5 \\
(13 \%)\end{array}$ & $\begin{array}{l}31.25 \\
(18 \%)\end{array}$ & $\begin{array}{l}10.25 \\
(6 \%)\end{array}$ & $\begin{array}{l}10.25 \\
(6 \%)\end{array}$ & $\begin{array}{l}10.25 \\
(6 \%)\end{array}$ & $\begin{array}{l}10.25 \\
(6 \%)\end{array}$ & $\begin{array}{l}10.25 \\
(6 \%)\end{array}$ \\
\hline 3 & PVP & $5.25(3 \%)$ & $14(8 \%)$ & $5.25(3 \%)$ & $3.5(2 \%)$ & $3.5(2 \%)$ & $3.5(2 \%)$ & $3.5(2 \%)$ & $3.5(2 \%)$ \\
\hline 4 & Starch & $26.25(15 \%)$ & $26.25(15 \%)$ & 0 & 0 & 0 & 0 & 0 & 0 \\
\hline 5 & Na Starch Glycolate & $3.5(2 \%)$ & $3.5(2 \%)$ & $3.5(2 \%)$ & $7(4 \%)$ & $7(4 \%)$ & $7(4 \%)$ & $7(4 \%)$ & $7(4 \%)$ \\
\hline 6 & Talc & $7(4 \%)$ & $74 \%)$ & $7(4 \%)$ & $7(4 \%)$ & $7(4 \%)$ & $7(4 \%)$ & $7(4 \%)$ & $7(4 \%)$ \\
\hline 7 & Colloidal Si Dioxide & $\begin{array}{l}1.75 \\
(1 \%)\end{array}$ & $\begin{array}{l}1.75 \\
(1 \%)\end{array}$ & $\begin{array}{l}1.75 \\
(1 \%)\end{array}$ & $\begin{array}{l}1.75 \\
(1 \%)\end{array}$ & $\begin{array}{l}0.88 \\
(.5 \%)\end{array}$ & $\begin{array}{l}0.88 \\
(.5 \%)\end{array}$ & $\begin{array}{l}0.88 \\
(.5 \%)\end{array}$ & $\begin{array}{l}0.88 \\
(.5 \%)\end{array}$ \\
\hline 9 & MCC & 0 & 0 & $26.25(15 \%)$ & $45.5(26 \%)$ & $\begin{array}{l}46.37 \\
(26.5 \%)\end{array}$ & $\begin{array}{l}45.5 \\
(26 \%)\end{array}$ & $\begin{array}{l}44.62 \\
(25.5 \%)\end{array}$ & $\begin{array}{l}43.75 \\
(25 \%)\end{array}$ \\
\hline 10 & SLS & 0 & 0 & 0 & 0 & 0 & $0.87(.5 \%)$ & $1.75(1 \%)$ & $2.62(1.5 \%)$ \\
\hline 11 & DRUG & $100(57 \%)$ & $100(57 \%)$ & $100(57 \%)$ & $100(57 \%)$ & $100(57 \%)$ & $100(57 \%)$ & $100(57 \%)$ & $100(57 \%)$ \\
\hline 12 & Total & 175 & 175 & 175 & 175 & 175 & 175 & 175 & 175 \\
\hline
\end{tabular}

Table 5: Post formulation parameters of the prepared aceclofenac immediate release tablets

\begin{tabular}{|c|c|c|c|c|c|c|c|c|}
\hline Batch code & Waightveriation & Hardness & Thickness & Friability & Drug content & Wetting time & Water ab ratio & Disintegration \\
\hline F1 & 177.9 & 1.6 & 2.43 & 8.72 & 90.6 & 30 & 228.83 & 27 \\
\hline F2 & 168.67 & 2.3 & 2.25 & 0.91 & 102.24 & 34 & 254.65 & 31 \\
\hline F3 & 176.24 & 2.6 & 2.52 & 0.38 & 97.96 & 25 & 211.27 & 28 \\
\hline $\mathrm{F} 4$ & 179.1 & 2.7 & 2.62 & 0.54 & 100.87 & 29 & 227.42 & 26 \\
\hline F5 & 173.08 & 3 & 2.69 & 0.89 & 91.95 & 28 & 309.64 & 26 \\
\hline F6 & 176.9 & 3 & 2.64 & 0.86 & 97.33 & 24 & 209 & 22 \\
\hline F7 & 176 & 3.1 & 2.59 & 0.88 & 94.12 & 24 & 203 & 23 \\
\hline F8 & 174.5 & 3.2 & 2.68 & 0.92 & 98.67 & 22 & 200 & 21 \\
\hline
\end{tabular}

Table 6: Dissolution study

\begin{tabular}{|c|c|c|c|c|c|c|c|c|}
\hline Time & F1 & F2 & F3 & F4 & F5 & F6 & F7 & F8 \\
\hline 0 & 0 & 0 & 0 & 0 & 0 & 0 & 0 & 0 \\
\hline 15 & 59.18 & 66.57222 & 54.22 & 69.95 & 56.26 & 71.65 & 75.47647 & 76.95 \\
\hline 30 & 79.52 & 73.72222 & 69.87 & 80.73333 & 77.84 & 84.22 & 89.64118 & 91.1 \\
\hline 45 & 84.3 & 76.46111 & 71.24 & 93.23333 & 86.12 & 87.32 & 89.68314 & 93.2 \\
\hline 60 & 91.2 & 80.85 & 83.42 & 93.3 & 90.44 & 91.65 & 94.66216 & 96.32 \\
\hline
\end{tabular}

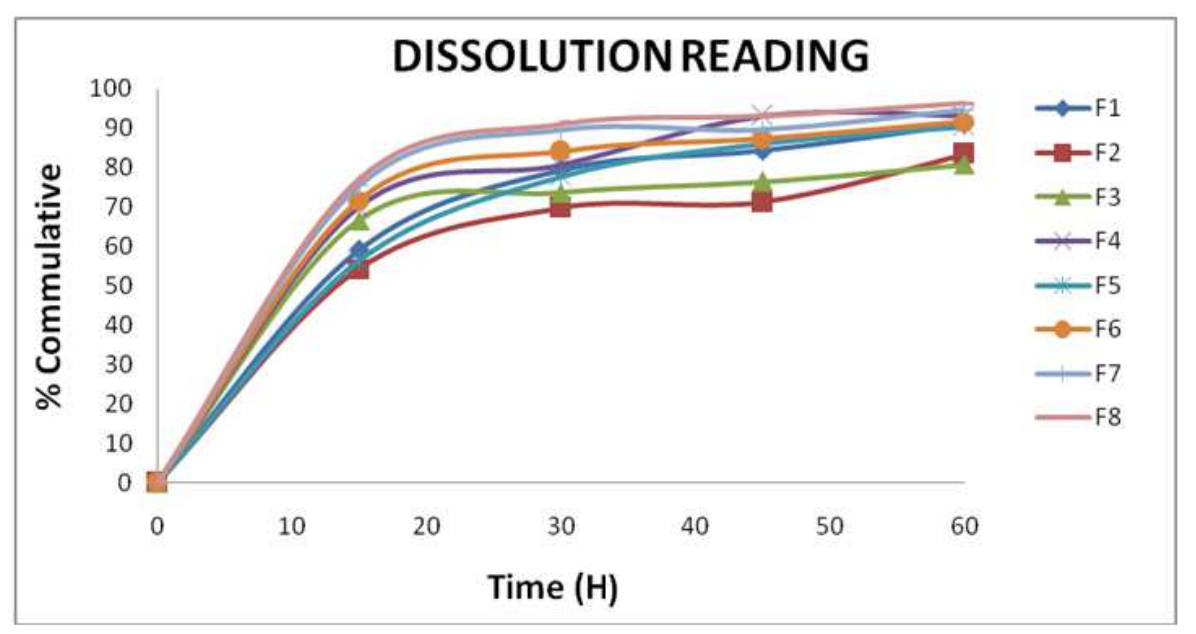

Fig. 3 


\section{RESULTS AND DISCUSSION}

The immediate release tablet of aceclofenac was prepared and evaluated for various parameters. The drug excipients compatibility study confirms that the drug was compatible for excipients, which were being used.

The pre-compression and post-compression parameters were obtained and were within the acceptable limits of the pharmacopoeial specification. The drug itself was a crystalline powder, colour is off white and it is odourless. The drug aceclofenac is insoluble in water, freely soluble in acetone and soluble in alcohol. From the flow property determination techniques (hournars ration, compressibility index and angle of repose) it was found that the flow property of the drug poor. For solving this, I have added Talc as lubricating agent and MCC also helps in increasing the flow property. The $\lambda_{\max }$ was measured and it was $273 \mathrm{~nm}$.

In the post formulation evaluation, it was found that all the tablets except F1 were within the range of pharmacopoeial standards. The hardness of all the formulation was found to be in good mechanical strength ranges from 2.3 to $3.2 \mathrm{~kg} / \mathrm{cm}^{2}$. The weight variation was found in all designed formulations in the range 168 to $179 \mathrm{mg}$. Friability of all the formulations were within the approved range $(<1 \%)$. Drug content was in the range between (90.6\%-102.24\%) which are within the limits. Disintegration time and water absorption ratio are in the limit and completes in less than 1 minute. The Drug release study showed that the increase in the concentration of super disintegrates gives an increase in disintegration time and water absorption ratio. The drug release was found between $80.85-96.32 \%$.

\section{CONCLUSION}

Immediate release tablets of Aceclofenac can be successfully prepared by direct compression techniques using selected super disintegrants (sodium starch glycolate) for the better patient compliance and effective therapy.

In the present study, the FTIR spectra for pure drug and its excipients were taken to establish the physical characterization of drug and its formulations. The result indicates the characteristic absorption bands for different functional groups and bonds present in the drug molecule before and after its formulation. It is observed that there is no shift in the position of characteristic absorption bands of pure drug and its formulations. It means that the drug remains in the same normal form in its pure state and after its formulations. Hence, it can be concluded in the present study the drug doesn't undergo any type of any change during its formulations.

All the tablets passed weight variation test as the average percentage weight variation was within $7.5 \%$ i.e. in the pharmacopoeia limits. The thickness was almost uniform in all the formulations and values ranged from $2.3 \mathrm{~mm}$ to $2.6 \mathrm{~mm}$.

Rapid disintegration within several minutes was observed in all the formulations. The in vitro disintegration data is tabulated in the table 5 . The in vitro disintegration time of immediate release tablets were found to be 21 to $31 \mathrm{sec}$, which is in the range of fulfilling the official requirements. By the addition of super disintegrants, the disintegration time decreased significantly.

The wetting time of tablets found to be in the range of 22 to $34 \mathrm{sec}$. The water absorption ratio is in the range 200 to $309.64 \%$. The water absorption ratio also changes with changing the different excipients but mostly affected by the super disintegrants.

$\%$ Drug content was in the range between (90.6-102.24) \% which are within the limits which indicate the uniform mixing.

The Drug release study showed that the increase in the concentration of super disintegrates gives faster release of the drug. The drug release was found between $80.85-96.32 \%$. It was also observed that $70 \%$ of the drug were released in $30 \mathrm{~min}$. as the pharmacopoeial standard. SLS performs a good role in the dissolution study, which helps in increasing the drug release and solubility of the drug.

The above results concluded that, all the prepared tablets were in the standard limits. Overall results indicate that formulation F8 which contain $2 \%$ PVP, 4\% sodium starch glycolate and $1.5 \%$ SLS was better one and satisfies all the criteria as immediate release tablet. The drug aceclofenac showing enhanced dissolution may lead to improved bioavailability, improved effectiveness and hence better patient compliance.

\section{CONFLICT OF INTERESTS}

Declare none

\section{REFERENCES}

1. Rane DR, Gulve HN, Patil VV, Thakare VM, Patil VR, Sharma A, et al. Formulation and evaluation of aceclofenac fast dissolving tablets. Int J Pharm Life Sci 2011;2:681-6.

2. Formulation and evaluation of fast dissolving tablet of albendazole. Int Curr Pharm J 2012;1:311-6.

3. RaoNGR, Kumar M, Reddy MS, Kistayya C, Reddy BM. Development and evaluation of fast dissolving tablets of fosinopril by a sublimation method. Int J Pharm Sci Drug Res 2012;4:230-5.

4. Pimple S, Joshi A, Maurya P, Swami A, Digge M, Singh R. Formulation development and optimisation of olmesartan medoxomil immediate release tablets. Int J Pharm Sci Drug Res 2015;7:395-400.

5. Sonje A, Yadav A, Chandra A, Jain DA. Formulation and evaluation of immediate release tablet of antihypertensive drugs according to bcs system. Int J Thera Appl 2012;7:18-24.

6. Sharma A, Jain A, Purohit A, Jatav R, Sheorey RV. Formulation and evaluation of aceclofenac fast dissolving tablets. Int J Pharm Life Sci 2011;2:681-6.

7. https://www.ncbi.nlm.nih.gov/pmc/articles/PMC3217689/. [Last accessed on $20 \mathrm{Feb} 2017$ ]

8. Yadav IK, Singh HP, Singh RP, Tiwari PK, Chandra D, Jaiswal D, et al. Formulation, evaluation and optimisation of aceclofenac sustained release matrix tablets. Int J PharmTech Res 2010; 1:592-8.

9. https://en.wikipedia.org/wiki/Aceclofenac. [Last accessed on 20 Feb 2017]

10. Patel KS, Junagade MS. Formulation and evaluation of immediate release tablet of mefenamic acid and dicyclomine hydrochloride by direct compression method. Int J Res Pharm Chem 2016;6:738-49.

\section{How to cite this article}

- Jahan Nur Rahman Hazarika, Pulak Deb. Formulation evaluation and optimisation of immediate release tablet of aceclofenac by direct compression method. Int J Curr Pharm Res 2017; 9(3):118-122. 